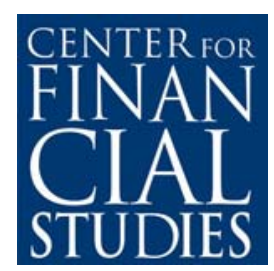

CFS WORKING PAPER

No. $2012 / 02$

Going Public - Going Private

The Case of VC-backed Firms

Andrej Gill and Uwe Walz 


\section{Center for Financial Studies}

The Center for Financial Studies is a nonprofit research organization, supported by an association of more than 120 banks, insurance companies, industrial corporations and public institutions. Established in 1968 and closely affiliated with the University of Frankfurt, it provides a strong link between the financial community and academia.

The CFS Working Paper Series presents the result of scientific research on selected topics in the field of money, banking and finance. The authors were either participants in the Center's Research Fellow Program or members of one of the Center's Research Projects.

If you would like to know more about the Center for Financial Studies, please let us know of your interest.

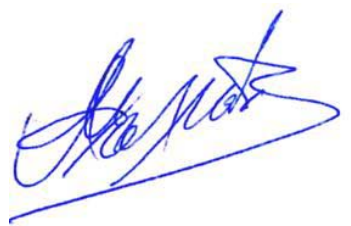

Prof. Michalis Haliassos, Ph.D.
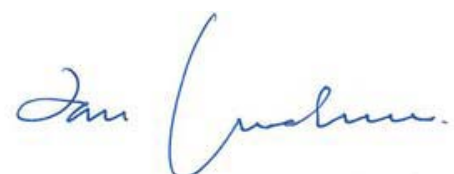

Prof. Dr. Jan Pieter Krahnen

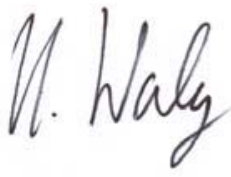

Prof. Dr. Uwe Walz 


\title{
Going Public - Going Private The Case of VC-backed Firms
}

\author{
Andrej Gill ${ }^{1}$ and Uwe Walz ${ }^{2}$
}

February 2012

\begin{abstract}
We investigate the decisions of listed firms to go private once again. We start by revealing that while a significant number of firms which go public is VC-backed, an overproportional share of these VC-backed firms go private later on (they stay on the exchange for an average of 8.5 years). We interpret this very robust pattern such that IPOs of VC-backed firms are to a large extent a temporary rather than a permanent feature of the corporate governance of these firms. We investigate various potential hypotheses why VCs actually seem to be able to bring marginal firms to the exchange by relating the going-private decisions to various characteristics of the IPO market as well as to VC characteristics. We find strong support for the certification ability of VCs: more experienced and reputable VCs are more able to bring marginal firms to public exchanges via an IPOs. These marginal firms backed-by more reputable and experienced VCs are more likely to go private later on. Hence, our analysis suggests that IPOs backed by experienced VCs are most likely to be a temporary rather than the final stage in the life of the portfolio firm. We find no support that reputable VCs underprice their IPO-exits more implying that they have no need to leave more money on the table to take the marginal firms public.
\end{abstract}

JEL Classification G24, G34, D80

Keywords Going-private decisions, VC-backed IPOs, corporate governance

\footnotetext{
* We are thankful for participants of the MOVE workshop on Venture Capital in Barcelona as well as of the Special Session on Entrepreneurial Finance, Venture Capital and Private Equity at the EFMA meeting in Braga, Portugal and of the Law and Economics workshop, Bonn for providing very helpful comments and suggestions.

1 Goethe University Frankfurt, Grüneburgplatz 1, 60323 Frankfurt, Germany. E-mail: gill@econ.uni-frankfurt.de

2 Goethe University Frankfurt and Center for Financial Studies, Grüneburgplatz 1, 60323 Frankfurt am Main, Germany. E-mail: uwalz@econ.uni-frankfurt.de
} 


\section{Introduction}

In the last decade we observed a very pronounced reduction of the number of firms listed on public exchanges of which a significant part is due to the going-private decisions of firms. In the US the number decreased by 40 percent (see Figure 1) in the 1999-2010 period. This process resembles a similar one in the 1980s which was followed by a subsequent going-public wave. An obvious and important issue is to investigate the driving forces of this going-private process. Rather, than addressing this issue in general (as in Mehran and Perstiani (2010) and Bharath and Dittmar (2010)) we address a specific, but in our view important aspect. By combing data on the going private process with data on $\mathrm{VC}$ backed IPOs we reveal that firms which have been backed by VCs at the time of their IPO are overproportionally more likely to leave to go private later on again. VC-backed IPOs are much more of a temporary nature as compared to firms which have not been VC-backed. In our data sample of US IPOs covering the 1975-2010 period, 79.9 percent of all firms which had initial VC-backing went private in the first ten years after their IPO as compared to 37.2 percent of all non-VC-backed IPOs. For the five period the number are obviously smaller but with of similar relative size (52.2 percent as compared to 17.4 percent). We show in a first step, that this pattern survives when we control for firm as well as market characteristics (such as hot-issue markets).

From this observation and the fact that initial conditions at the time of the IPO have predictive power for the going-private decision (i.e. the observation that marginal firms which just made it to the exchange are more likely to leave the exchange later on via a going-private decision) we derive our main research questions. First, why are VCs more able and willing to bring marginal firms to the exchange. Second, do VCs compensate shareholders for buying shares of these firms, e.g. via underpricing?

In order to answer the first question we explore three potential hypotheses, namely that VCs are especially able to time the market and bring marginal firms to the exchange. Furthermore, we investigate the possibility that VCs have an incentive to grandstand, i.e. young VC firms having an incentive to exit their portfolio firms to an overproportional degree via an IPO to signal their quality and ability to select and nurture promising firms. Finally, we explore the certification hypothesis implying that especially experienced and reputable VCs can use their characteristics to bring their marginal firms to the exchange. Testing these hypotheses with our data set which covers a large part of all US IPOs in the time period between 1975 and 2010 reveals that we do not find support neither for the timing nor for the grandstanding hypothesis. Our analysis, however, indicates that measures for $\mathrm{VC}$ experience and reputation (derived partially from a recent study of Nahata (2008) on the link between VC reputation and performance in the pre-IPO period) of the $\mathrm{VC}$ which brought the firm initial to the exchange have a positive and significant impact on the going-private probability. This finding clearly supports our certification hypothesis implying that indeed more experienced and reputable VCs are able and willing 
to bring marginal firms to the market. This implies, that for those firms, the IPO is just a temporary step in their life-time which is reverted rather soon and which is brought about by the potential of the lead VC to overcome informational asymmetries in a better way as compared to firms which have been going public with less experienced VCs or those firms which went public on their own.

Our paper is closely related to two branches on the literature. On the one hand it contributes to the literature on the going-private process and indirectly also on the goingpublic decision. A number of recent papers have addressed in detail the going-private decision (see in particular Bharath and Dittmar (2010) and Mehran and Perstiani (2010)). None of these paper has, however, investigated the role of VCs and VC-backing in the going-private process. There is also a large literature on the determinants of the choice between being public or private, theoretical (see e.g. Zingales (1995)) as well as empirical (see e.g. for a discussion Ritter and Welch (2002) and for a recent contribution T., He, and Nandy (2010)). Thereby, the role of venture-backing in determining the optimal corporate governance scheme (i.e. being a public or private company) has not played an important role. With this back we aim to address this issue in detail and link the role of VCs in the going public decision with the going-private process.

Furthermore, our paper is closely related to the literature on the exit choice of VCs. The choice of VC exit via an IPO has played a decisive role in this literature. Starting with Black and Gilson (1998) a substantial number of papers have addressed the choice of exit mode of the VC via acquisitions or IPOs (see e.g. Giot and Schwienbacher (2007) and Bayar and Chemmanur (2011)) as well as the issue of exit timing (see e.g. Giot and Schwienbacher (2007) and Neus and Walz (2005)). In addition, the literature on VC exit decisions (via IPOs) has looked into the implications of this decisive decision on the contractual relationship between VC and entrepreneur (see e.g. Cumming (2008) and Cumming and Johan (2008)). But most of these paper address the time at the IPO or prior to the IPO. The only exception to this are papers investigating the post-IPO financial performance of VC-backed firms (see e.g. Brav and Gompers (1997)). However, the dynamics of the corporate governance of VC-backed firms in the aftermath of the IPO has not yet analyzed. By looking into the dynamics of the firm's governance after the VC-backed IPO (with the specific focus on the going-private decision) we aim to bring the literature on VC exits and the literature on the firm's decision to be a public or private company together.

The paper is organized as follows. In the next section we discuss some aggregate data thereby trying to shed some light on the overall patterns our paper relies on. In the third section we introduce our data set and provide some descriptive statistics on the goingprivate decision. The fourth section concentrates on the going-private decision. The main aim of this section is to show that our pattern that VC-backed firms are much more likely to go private some years after their IPO survives if we control for firm and market characteristics in a Cox proportional hazard model. The fifth section is devoted to deriving 
some hypotheses which may explain the ability and willing of VCs to bring marginal firms to the exchange. In the sixth session we test these hypotheses as well as investigate whether VCs are underpricing their issues systematically. The seventh section contains an extension and a robustness check of our basic analysis. The last session concludes.

\section{Some aggregate data}

In order to get a first impression on the dynamics of the going-public and going-private process we provide some aggregate data which we consider rather revealing.

Figure 1 clearly reveals the fluctuations in the going public process. Whereas the IPO market was booming in the 1990s, the number of IPOs were significantly reduced in the post 2000 decade. In the 1980s we observe strong fluctuations in the yearly IPO figures. These fluctuations are even more pronounced if we consider the gross proceeds resulting from these IPOs. Given the large number of IPOs we would expect an ever increasing number of listed firms in the US.

Insert Figure 1 here

Looking into the data, however, reveals that this conjecture does not hold true. Rather, beginning in 1999, we observe a very significant drop in the number of listed companies (see figure 2). The number of listed companies almost halved in the years after 1999 . Starting from almost 9,000 firms which were listed in the 1999, this number decreased to little more than 5,000 firms in 2010. Theoretically this could be due to the fact that a number of IPOs were not financially viable and were forced by bankruptcy to leave the exchanges. While there are companies which went bust, this is only part of the story at most. Rather we observe a pronounced going-private process throughout the entire time span (see figure 3). Delisting took place at a very significant pace in the 1998-2010 period. But even in calmer respective periods, significant number of IPOs and delistings occurred. Even in the 1990s with its very active IPO market, a minimum of 20 firms went private with a maximum of more than 140 firms deciding to go private once again in 1990. In the 2000s the number of going-private cases was persistently high, often exceeding 100 firms which went private per year and never falling below 60 firms per year.

Insert Figures 2 and 3 here

In both, the going-public as well as the going-private process, venture-backed companies play a crucial role. Figure 1 provides a first indication of the role of VC-backed companies in the going public process. The figure reveals that throughout the entire span of our observation period the share of VC-backed IPO never went below 20 percent (from the 
1980s ongoing), reaching in a number of years even more than 60 percent of all IPOs. This just reflects the fact that IPOs are a decisive exit channel for VC investments (see Black and Gilson (1998) and Jeng and Wells (2000)) on this. VCs as intermediaries standing in-between their investors and the portfolio firms are in very many cases designed as closed-end funds implying that they have to disinvest their ventures after a quite limited number of years (typically, the closed-end funds last for 10-12 years, see e.g. Gompers and Lerner (2004))). Thereby, they have two major alternatives at hand to sell their shares in their successful portfolio firms: either to sell the entire firm to another firm in the course of a trade sale or to opt for an initial public offering and to divest in the course of the going-public process (see e.g. Nahata (2008)). Our numbers suggest that especially in the 1990s disinvestment via the IPO route was rather dominant, while it lost momentum in the post 2000-period (see e.g. Kyriakos and Ueda (2007)) in line with the low dynamics of the IPO market in general (see figure 1).

The number depicted in Figure 3 clearly reveal that VC-backed firms are overproportionally likely to go private again. While throughout our entire time period 45 percent of all firms who go public are venture backed of those firms which go private later on, more than 80 percent have been initially been backed by a venture capitalist. This overproportional share of firms backed by VCs at the time of the IPO which go private later on is at the center of our paper. We aim to investigate this matter in much more detail and aim to discover whether it survives a more scrutinized investigation. These first rough and aggregate numbers, namely, only suggest rather than show that the fact that a firm at the time of the IPO is VC-backed is determining their likelihood to go private again in a positive manner. In order to get a more accurate picture and to avoid that some other common characteristic of VC-backed firms (e.g. their age at time of the IPO) is driving the later going-private decision we have to investigate the data in more detail and control for other factors potentially influencing the going-private decision.

We pursue our analysis in two mayor steps. In the first step, we investigate the determinants of the going-private decision and ask whether, after controlling for many other factors, it remains still the case that the fact that a firm was VC-backed at the time of the IPO makes it significantly more likely that this firm will go private once again. Our answer to this question will be affirmative: venture capitalists seem to be able to bring "marginal" firms (i.e. those with characteristics which just make them suitable for the going-public process) on the stock exchange. On this basis of this affirmative answer, we turn to our second step, which is very much the main focus of the paper. There, we investigate, potential reasons why venture capitalists are able and willing to bring these marginal firms public. This analysis is founded on a number of hypotheses derived from the venture capital and the going-public literature. 


\section{The data set}

\subsection{Data sources}

The key innovation of our data set is the fact that we have merged IPO data and information on going-private decisions with data on VC-backed IPOs as well as data on underlying VC characteristics. Thereby, we use the Center for Research on Security Prices (CRSP) data base as source for the going-private decisions. With respect to the goingprivate decision we code the following CRSP deletion codes as going-private: "mergers" (corresponding codes: 200 - 300) and "dropped" (corresponding codes: 500 - 600). All information on market prices are also from CRSP data base. We complement the information on the going-private decision of CRSP with the Compustat information on the going-private process (i.e. whenever we obtain missing information from the CRSP data base while having information from Compustat on a going-private case we complement our data set with the latter). The corresponding reasons for deletion in Compustat are: acquisition or merger, reverse acquisition, leveraged buyout as well as "now a private company". Furthermore, we extract the firm data on balance sheet information from this data base as well. The information on VC characteristics stem from SDC Platinum, in particular from Thomson's Venture Expert data base. Information on IPOs (date of IPO plus IPO price) are derived from all three data bases. Furthermore, we use data on firm age at the time of the IPO which are provided by Jay Ritter on his website. Our data set covers US IPOs and going private case from 1975 onwards.

\subsection{Variable Descriptions}

We look into two sets of variables which might potentially have an effect on the goingprivate decision: firm (and market) characteristics at the time of the IPO and variables which reveal changes in firm characteristics during the time firms have been public.

Table 1 provides an overview on the main variables of our data set.

Insert Table 1 about here

\subsection{Descriptive statistics}

In the first step of our detailed empirical analysis, we investigate the determinants of the going-private decision of the firms in our data set, in particular of firms which have had VC-backing at the time of the IPO. As a first insight, we present some descriptive statistics before turning to a more detailed multivariate analysis in the next section. 
We split the descriptive analysis in two steps. In the first one, we provide a comparison of going-private sample with the control group. This allows us to gain some first insights into the determinants of the going-private process. In the second step, we distinguish firm and industry variables for VC-backed and non-VC-backed firms. This distinction allows us to shed light on a potential selection bias of VC-backed firms, a bias we need to control for in our multivariate variable to ensure that it is indeed the fact that firms are VC backed which increase the likelihood that they go private eventually rather than simply reflecting a selection bias. The multivariate analysis expands the descriptive analysis.

\subsubsection{Going-private versus staying-public sample}

Table 2 provides the descriptive statistics for the comparison between the going-private sample and the control group. It reveals that a number of firm characteristics at the time of the IPO significantly differ between the going-private sample and the control group. We report means as well as medians of the two samples. For both cases we conduct mean-comparison and Wilcoxon signed-rank tests to detect statistical significance of the respective variables between the two subsamples. The main findings are as follows. Firms which went private later on were significantly younger (mean: 11.63 years, median: 7 years) as compared to their counterparts in the control group (mean: 18.89 years, median: 9 years). In addition, our comparison of means indicates that firms which went private again were also on average smaller at the time of the IPO in a number of dimensions. This is the case with respect to sales (mean: 166.1 mill compared to 637.6 mill; median: 29.88 mill. USD compared to 60.36 mill USD) as well as with total assets (mean: 316.9 mill versus 1382 mill; median: 50.01 mill versus 111.5 mill.). Differences between the two subsamples are significant at the one percent level for these two size variables. In addition, our univariate comparisons suggest that firms belonging to the going-private sample have significantly lower leverage and need less access to capital (as measured by the fact that they have significantly better relative cash holdings as well as paying less often dividends). Somewhat surprising, our measure of capital constraints, the Kaplan-Zingales Index reveals that firms which go private later on have a much lower Kaplan-Zingales index than their counterparts, thereby indicating less financial constraints associated with the sample of firms which goes private later on, but these differences are not statistically significant. Overall, this suggests that there are, already at the time of the IPO differences between the two subsamples, i.e. those firms which remain on the exchange and those which do go private later on.

Insert Table 2 here

Table 3 reveals that besides differences in initial conditions at the time of the IPO we also observe differences with respect to five-year growth rates after the IPO. 
Insert Table 3 here

There are no clear-cut patterns in the differences of the growth path of firms in the two different subsamples. Often the differences between the two subsample vary in sign when comparing the differences in means and the differences in median values, indicating rather skewed distributions. This is true for example with regard to sales growth. With respect to asset growth we find that firms which grow faster are more likely to stay on the exchanges while those which grow more slowly more often leave the exchange later on. With respect to market value we find that firms which go private tend to have a smaller growth rate in market value. The change in capex/sales as well as the change in market-to-book is smaller for the going-private firms compared to their counterparts in the control group. The growth rate in cash/total assets is smaller with the going-private subsample indicating that initial differences between the two subsamples became smaller over time.

All this suggests that changes over time (i.e. after the IPO) and hence the development of the firms differ across the two types of firms. Thereby, we find indication that firm dynamics seem to have had an effect on the going-private decision. This is, however, definitively also true for firm characteristics at the time of the IPO. Firm characteristics at the time of the IPO seem to have predictive power which of the firms will stay on the exchange and for which this is only a temporary episode in the life-time of the company. Hence, firms which share these characteristics can be called marginal firms, i.e. firms which just were suitable for an IPO. The fact that we observe a very high proportion of VCbacked firms which went private later on lets us conjecture that VCs are more able and willing to bring such marginal firms to the public markets. An alternative interpretation is that VCs are more likely to have invested in these marginal firms. That is, the alternative interpretation is that firm characteristics, rather than the fact that the $\mathrm{VC}$ itself is able to bring them to the public market, is responsible for the fact that we see more VC-backed firms to eventually go private. A first step towards disentangling these two interpretations is to investigate potential differences in firm characteristics at the time of the IPO between the sample of VC-backed firms and firms which have had no VC backing. Only if there are significant differences between the two, the alternative interpretation is a potential candidate for explaining the observed patterns.

\subsubsection{VC-backed vs non-VC-backed firms}

Table 4 delineates potential differences in firm characteristics between VC-backed firms and firms which did not have any VC capital at the time of their IPO. A look on this table reveals that VC-backed firms are significantly different from non-VC-backed IPOs in a number of dimensions. First and foremost, we observe that VC-backed firms have been significantly younger at the time of the IPO as compared to their non-VC-backed 
counterparts. The difference in age amounts to 4 years with respect to the median and 8 years in the mean. Furthermore, VC-backed firms are significantly smaller than non-VC backed firms (wit respect to sales as well as to total assets). In addition, VC-backed firms are on average more R\&D intense and less levered (indicating their lower debt capacity). Overall, this fits quite well into the overall notion, that VCs invest in R\&D intense, young firms with rather few tangible assets.

Insert Table 4 here

Hence, we clearly see support for the selection hypothesis. But, even if there is a selection effect, this still might imply that VCs are better able to bring marginal firms to the exchange. In order to separate this effect from the pure selection effect, we need to control for firm characteristics in a multivariate analysis. If, after controlling for these firm characteristics, a significant effect of VC-backing at the time of the IPO remains, this would strongly support our conjecture that it is indeed VC-backing per se which allows marginal firms to go public (leading to a higher probability to go private once again later on). If we get support for this conjecture in the course of our multivariate analysis, we turn to the second issue, namely what drives this fact that VCs are more able and more willing to bring marginal firms to the exchange.

Before, we move on, it is appropriate to discuss on potential caveat against this procedure, namely the argument that not firm characteristics at the time of the IPO but rather at the date at which the VC invests in the firm matters for the selection. Looking at firm characteristics at this point in time (an information which is by the way not available to us) however, overlooks

\section{Analysis of going-private choice}

We first start with our analysis of going-private decision in a multivariate setting by making use of the panel structure of our data set. The dependent variable is time since the IPO. Thereby, we employ one of the most widely used duration model, the Cox proportional hazard model. This particular type of a duration model is particularly helpful when the exact time of each 'exit' is known, a property which is fulfilled in our data set. The proportional hazard model describes the (instantaneous) hazard function $h(t)$ as a vector of explanatory variables $x$ with unknown variables and $h_{0}$ as the baseline hazard rate: $h(t)=h_{0} e^{x^{\prime} \beta}$. In our context, the hazard rate depicts for every particular firm the probability of going private. More precisely, the instantaneous hazard rate $h(t)$ denotes the probability of going private in a (short) time spell (between $t$ and $t+d t$ ) given that it has not gone private up to $t$. The Cox proportional hazard model can be used to estimate $\beta$ without specifying the form of the baseline hazard function $h_{0}$ (see Kiefer, 
1988, p. 667). As such, the hazard rates $\left(\exp \left(x^{\prime} \beta\right)\right)$ are easily computable from the reported coefficients, which measures the economic significance of the coefficient estimates. The first two columns of table 5 present the result of the Cox regressions. These columns denote, for given values of the independent variables, the conditional probability of going private. Hence, the signs of the coefficients are readily interpretable. A positive coefficient implies a higher probability of going private the larger is the value of the respective independent variable. Conversely, a negative coefficient implies that a higher value of the independent variable is associated with a lower probability of going private. The estimation results of the Cox proportional hazard model are displayed in Table 5. The interpretation of the coefficients is straightforward: they display the likelihood to go private as a consequence of the increase of the independent variable by one unit. For example, the coefficient of 1.813 in the first column of our table denotes that the differences in the probability to go private between VC-backed and non VC-backed firms is 181.3 percent. This implies that if on average the going-private probability of a non- $\mathrm{VC}$ backed firm is 30 percent, the respective probability of the VC-backed firm is 84 percent.

The results in table 5 reveal that the results of the univariate analysis in general carry over to the Cox regressions: size, as measured by the sales variable as well as market value has a negative effect on the going-private probability. That is, smaller firms are more likely to go private again. Younger firms (Age at the time of the IPO) display a significantly higher probability of going-private. In addition, the analysis reveals that firms which pay little dividends (and hence have better financing conditions) are more likely to go private. For our purpose, the most important result, however, is that the VCbacked variable remains highly significant. This is true for both our Cox models where we included in the second one a control variable which we consider to pick up the potential selection effect displayed by VC-backing, namely the R\&D intensity of the firm. It turns out, however, that this variable (which also leads to a rather sharp drop in the number of observations) has no significant effect on the going-private decision (see Table 5) and leaves all the other factors, most notably the VC variable unchanged. Thereby, we note the very pronounced statistical significance level (at the one percent level) but also the very pronounced significance of the economic effect.

Insert Table 5 here

In order to get a better understanding of the determinants of the going-private process, which is then also helpful in analyzing the VC-backed phenomenon, it is decisive to ask in a multivariate setting whether it is i) the development firms undertake when they are listed or ii) firm as well as market characteristics which determined the going-private decision. For this purpose we look into the explanatory power of a probit regression which only focuses on variables which measure firm as well as market characteristics at the time of the IPO. Our findings in column three of table 5 reveal that a number of firm 
characteristics at the time of the IPO have predictive power for the going-private decision which takes place years later. This is true for the sales variable as well as for market value variable both having a negative, statistically significant coefficient. In addition, we find a negative and statistically significant Kaplan-Zingales index, indicating that firms which are financially constraint seek access to public markets and hence stay on the exchange while those with a low Kaplan-Zingales index are more likely to go private. Overall this reinforces the findings of our univariate analysis. Furthermore and not astonishingly, the fact that firms are VC-backed has also a statistically significant influence on the goingprivate decision in the probit regression.

Taking this together shows that initial firm characteristics matter at the time of the IPO. This clearly suggests that "marginal firms measured at some critical characteristics (size, age, ...) as well as the fact whether these firms are VC-backed are significantly more inclined to reverse their initial going public decision. From this observation, two decisive questions arise. First, why do VCs have the ability but also willingness to bring these marginal firms public? Second, how does "corporate-governance performance (i.e. turning first from a private company to a public one and then reverting eventually back) relate to the financial performance of firms while they are public? We address these two questions in the following, while putting particular emphasis on the former one. In order to address the first question in some detail we first address the existing literature on VC exit decisions as well as on the IPO decision in general aiming to carve out some theoretical hypotheses which allow us to address and potentially answer our first question: why are VCs able and willing to bring marginal firms public?

\section{Potential reasons behind the VCs willingness/ability to bring marginal firms public}

Exit decisions are decisive in the investment cycle of the VC (see e.g. Black and Gilson (1998)). There is a significant body of literature dealing with many aspects of the exit decisions. We focus in the following, however, on studies which are addressing potential determinants behind the going public decision. For successful investments VCs face two exit related decisions: the choice on exit mode as well as the choice on exit timing. We identify three main arguments which could potentially answer why VCs are able and willing to bring marginal firms public.

First, Lerner (1994) addresses the question whether VCs are indeed able to time the market, i.e. bring their portfolios firms public especially und when equity valuations are high. VCs are in most cases able to decide on the going public decisions of the portfolio firms. Since VCs hold exit rights they have a crucial say not only on the exit mode but also on exit timing in most of their ventures (see e.g. Aghion, Bolton, and Tirole (2004) and Bienz and Walz (2011)). Furthermore, VCs have an interest to time capital markets 
despite the fact that they are selling only a small proportion of their share holdings at the time of the IPO (see Lin and Smith (1998)). This is due to two circumstances. On the one hand, bringing portfolio firms public in hot-issue markets leads to less dilution of the VC because a given sum of capital is collected with the issuance of a smaller number of shares (see Barry, Muscarella, III, and Vetsuypens (1990)). On the other hand, underpricing, which is cheaper in hot-issue markets, allows for the build-up of reputation vis-a-vis investors in capital markets for the VC (see Grinblatt and Hwang (1989) for evidence).

Lerner (1994) finds, that VCs indeed are timing the market, i.e. bringing overproportionally many portfolio firms public, relative to a non-VC backed control group public during hot-issue markets. Furthermore, he finds in his data set, that more experienced VCs are most capable timing capital markets.

From these findings we derive our first hypothesis

Hypothesis 1 Market timing: VCs are able to time capital markets allowing them to bring marginal firms public in hot-issue markets. This market-timing ability is most pronounced with seasoned VCs. Hence, we should expect that VC backed firms which go public are most likely to go private later on. The highest likelihood of going private should be observed for those firms backed by an experienced VC in a hot-issue phase of the capital market at the time of the IPO.

Second, Gompers (1996) stressed that VCs have an incentive to grandstand. Especially, new and inexperienced VCs have an incentive to signal their ability to the market, i.e. to their potential investors. Given that VCs are typically organized as limited partnerships and closed-end funds, they need to raise new capital when the life-time of a fund ends. The main decision variable for investors (limited partners) is the quality of fund managers (general partners) to select and nurture promising venture. Hence, general partners have a strong incentive to convince potential limited partners about their abilities and to build up a reputation of being a capable $\mathrm{VC}$ investor. One of the most obvious signals general partners can send is to bring one of their portfolio firms public. Since the build up of reputation is decisive for fund raising VCs are even willing to incur costs to build up such reputation (e.g. in form of a higher degree of underpricing). Gompers (1996) argues that while there is less necessity for older and reputable VCs to invest in reputation, especially younger VCs have an incentive to incur the costs of investing in reputation. There, these younger firms have an incentive to grandstand, that is, bring their portfolio firms public more often and earlier as compared to established VCs. This notion of grandstanding - and the associated willingness of less established VCs to incur the costs of bringing portfolio companies to the public markets more often and sooner in the former of a higher degree of underpricing - is supported by Lee and Wahal (2004b). They find that indeed the degree of underpricing depends negatively on VCs reputation (measured by VC age and the number of previously conducted IPOs by this VC firm). 
This implies that less established VCs are more likely to bring marginal portfolio companies to the public markets. These firms are less mature and less likely to benefit from public markets while at the same time are less able to bear the costs of being public (e.g. lacking a big shareholder). Hence, we would expect these firms to share a higher probability of going private later on once again.

This leads us to our second hypothesis:

Hypothesis 2 Grandstanding: VCs with a lower level of reputational capital (i.e. younger VCs and those with fewer previous IPOs) are more likely to bring marginal firms to the public markets. Firms backed by those VCs have a higher likelihood to go private again later on.

A third line of argument goes back to Megginson and Weiss (1991). They argue against the background of their observation that VC-backed IPOs were less underpriced than their non VC-backed counterpart, that VC certify the quality of their portfolio firms and hence may overcome informational asymmetries. This certification ability of VCs (see on a discussion of the certification hypothesis e.g. Li and Masulis (2006) and Lee and Wahal (2004a)) may allow them to bring marginal firms to the markets. Especially experienced VCs should be most able to exercise this certification role. This is in line with a recent study by Nahata (2008) who shows that portfolio firms which are backed by more reputable VC are more likely to go public and access public market faster. In addition, his findings imply that experienced and reputable VCs back firms which are more successful as measured by asset productivity. We conjecture that these marginal firms are then among the first to leave public markets later on. In the group of VC-backed firms this argument would imply that especially firms backed by experienced and reputable VCs are the ones who are most likely to leave the public market via a going-private decision. ${ }^{1}$

We therefore can state for our third hypothesis:

Hypothesis 3 Certification: VCs are able to certify the quality of their firms, thereby enabling them to bring firms to public markets at lower costs. These firms are then more likely to go private later on once again. Since established VCs are obviously best suited to certify the quality of their firms, firms backed these established VCs are most prone to leave the public exchange later on.

\footnotetext{
${ }^{1}$ A seemingly similar argument, namely the one of Barry, Muscarella, Peavy, and Vetsuypens (1990) who argue that lower underpricing in VC-backed IPOs is driven by the capability of VCs to select and monitor the portfolio firms properly has quite different implications in our context. Better screening and monitor makes VC-backed firms more mature allowing them to do better in public markets as compared to their counterparts. If this selection and monitoring mechanism does not show up in our firm characteristics we are controlling for we should observed less VC backed firms to go private once again. If selection and monitoring is revealed in the control variable we should not observe an effect.
} 


\section{Hypotheses tests}

We approach our hypotheses empirically by introducing proper proxies for our hypotheses in our standard Cox regression.

We start by addressing the hot-issue market hypothesis (see table 6). We employ three different proxies for hot-issues markets. The first is the most natural and direct proxy: the number of IPOs at the time of the IPO (see also Ritter (1984) on this in his classical article on hot-issue markets). Secondly, we control for the sizes of the respective IPOs by using the aggregate IPO proceeds in the fiscal year in which the respective firm went public. Our third proxy variable measures the annual returns in the NASDAQ for the fiscal year in which the respective firm went public. In all our regression we rely on our standard Cox regression set-up from the previous section. For all three proxies we look into the role of hot-issue markets per se as well as on the role of hot-issue markets for VC-backed IPOs. We find a rather clear-cut picture which does not support hypothesis 1. While firms which went public in a hot-issue market are significantly more likely to leave the exchange after a couple of years, the same is not true for VC-backed IPOs. Just to the contrary, VC-backed firms which went public in hot-issue markets are significantly less likely to go private later on. These findings are very strong for two of our proxy variable, the IPO proceeds variable as well as the NASDAQ variable, while we find no significant relationship for number of IPOs variable. With the two former variables the coefficient of the variable itself is positive and highly significant. However, the interaction term of these variable with the $\mathrm{VC}$ dummy is negative and also significant. This implies that in general firms which went public in hot-issue markets have a significantly higher likelihood to go private, whereas the opposite is true for VC-backed firms.

Insert Table 6 here

Our interpretation of this finding is that it seems to be indeed the case that during hotissue markets marginal firms (i.e. those firms which just fit to the exchange) go public. This general finding does not apply for VC-backed firms. Just to the contrary: VCs accompany significantly less marginal firms to the exchange during hot-issue markets. Figure 1) clearly supports this view. It reveals that VCs rather than contributing to hot-issue markets almost do the opposite: the higher the number of IPOs in a particular year, the lower is the share of VCs in particular and vice versa. The correlation coefficient between the total number of IPOs and the share of VC-backed IPOs for the post 1980 period (before 1980 too few observations distorts the picture) is negative (-0.469) and highly significant different from zero (at the one percent level).

We address the grandstanding and the certification hypothesis jointly. In order to test the two hypotheses we need to establish proxies for VC-experience and reputation. The most direct variable which measures the experience of the $\mathrm{VC}$ firm is the age of the $\mathrm{VC}$ 
firm at the time of the IPO of the portfolio firm (AGE-VC). We thereby rely on the VC firm rather than the $\mathrm{VC}$ fund since the information on the $\mathrm{VC}$ firm reflects the ability of the VC firm to raise follow-on funds allowing them to invest in further portfolio firms. Raising follow-on funds requires, however, sufficient performance which makes investors inclined to invest in the follow-on fund of the VC firm once again. Hence, the age of the VC firm also measures the quality of the VC firm. In contrast, the age of the VC fund is a simple indication of the speed at which the particular $\mathrm{VC}$ fund invest his committed capital in portfolio firms. There is little, if any relationship to the experience of the VC. There is, however, some noise associated with the age of the VC variable, especially for captive VCs such as bank-dependent VCs for which this variable sometimes measure the age of the parent company. In order to avoid this to happen, we exclude all VC firms which are indicated to be older than 60 years.

As a second variable we make use of the fact that we have information on the number of previous IPOs of the VC firm. VCs exit their most successful firms via an IPO (see Giot and Schwienbacher (2007) and H. and Cochrane (2005)) making the number of previous IPOs not only an indicator of VC-experience but also of reputation. We refer to this variable as NUMBER-IPO-VC. Third, we employ the information on the type of the VC. We distinguish captive VCs from independent once. It has often been argued and shown that the latter type of $\mathrm{VC}$ is more active in their portfolio firms and therefore more able to certify the quality of the portfolio firm (see e.g. Hirsch and Walz (2012))). Therefore, we create a dummy on the VC type which take a value of one if the VC is an independent $\mathrm{VC}$ and zero if it is a captive VC (DUMMY-INDEPENDENT).

Last but not least, we employ a variable which has been proposed and used recently by Nahata (2008) in his study on VC performance. He constructs a variable which measure each VC's firm share in the accumulated market capitalization of VC-backed IPOs up to the year of the IPO of the respective VC-backed firm. In order to do so he adds up the market capitalization of all previous IPOs of the VC firm up to (and including it) to the IPO of the respective VC-backed firm. This number is then divided by the accumulated market share (up to this point in time) of all VC-backed IPOs. We refer to this variable as MARKET-SHARE-MCAP-VC.

Surprisingly, these variables are little correlated. The strongest correlation exists between the NUMBER-IPO-VC variable and AGE-VC variable (0.189). Both variables are little correlated with the MARKET-SHARE-MCAP-VC variable. The correlation coefficient of this variable with number of previous IPOs of the respective VC firm is even slightly negative $(-0.0035)$ while the other correlation coefficient is 0.0234 .

In order to test our grandstanding and certification we use our standard Cox regression and add these four proxies for $\mathrm{VC}$ experience and reputation in different regressions. First, we use the four different VC proxies, while testing them in a second step jointly into the Cox regression. While the grandstanding hypothesis would suggest that we get negative and statistically significant coefficients for all four variables the opposite holds 
true for the certification hypothesis. Table 7 displays our results. Models 1 and 2 in Table 7 indicate that the number of IPOs brought to the market by the respective VC as well as the VC age variable do not have a statistically significant effect on the going-private decision. Both coefficients are positive but far from being statistically significant. The picture is quite different when we turn to the variable which measures $\mathrm{VC}$ experience and reputation via the role of the respective VC in the IPO market, namely through the accumulated sum of the market capitalizations of this VC, relative to the overall market capitalization of all VC backed IPOs. This measures which takes care of different sizes of IPOs and weighs larger IPOs stronger has a positive and statistically significant impact on the going-private decision (see model 3 in Table 7). This effect remains robust when we insert all the four variables measuring VC experience and reputation in the standard Cox regression (see model 5 in Table 7). Very much the same result emerges for the VC type variable: the effect of the dummy variable indicating that an independent $\mathrm{VC}$ which has been backing the portfolio firm is positive and statistically significant (see model $4 \mathrm{in}$ Table 7). This effect, once again, carries over to the full model with all proxy variables representing VC experience and reputation (see model 5 in Table 7). Taking these findings together, we can interpret our findings as clear support for the certification hypothesis. More experienced and reputable VCs are better equipped to bring marginal firms to the exchange. Our results also indicate a clear rejection of the grandstanding hypothesis. We find no support for the conjecture that especially young and unexperienced VCs have had the ability to bring marginal firms to the exchange.

\section{Insert Table 7 here}

It is interesting to view our results against the background of the findings of Nahata (2008). Nahata (2008) shows that experienced and reputable VCs (as measured by the MARKET-SHARE-MCAP-VC variable) are more likely to exit their ventures successful venture. He also finds that more reputable VCs exit their ventures faster. We complete this picture of the evolution of VC-backed firms, by adding a, what we think very important piece. Our findings clearly suggest that this success, at least from a corporate governance point of view is only a temporary one. Firms backed by more reputable and experience firms seem to be more likely to be successful (with respect to the exit per se, but also as suggested by Nahata (2008) with respect to asset productivity), but of those firms which end on listed exchanges via an IPO, the ones with a backing of a more reputable are also significantly more likely to go private later on again. Hence, we can stress that for many VC-backed firms in general, the IPO is not the final step in the firm's corporate governance, but rather a temporary one. This in particular true for firms backed by reputable and experienced VCs. All this sheds very strong doubts on the view which at least implicitly exists in the literature on venture capital: the IPOs as the silver bullet for the portfolio firms. Rather, it seems to be the case that being listed is only a temporary part of the life-time of formerly VC-backed firms. The certification ability of the VCs 
allows marginal firms to become a public company but after the $\mathrm{VC}$ has left the firm (entirely) being public obviously proves to be not optimal anymore, i.e. firms go private once again.

Finally, we address the question, whether VCs pay for their ability to exit marginal firms through an IPO via a large degree of underpricing (i.e. leaving sufficiently much on the table in the course of an IPO). In order to do we regress the level of underpricing on firm as well as VC characteristics (see Table 8). We find rather little support for this mechanism (see Table 8). The variable which proved to be significant in the test of the certification hypothesis has no explanatory power in the underpricing regression. Only the variable measuring the number of previously initiated IPOs by the respective VC has a significant and positive effect. Our interpretation of this finding is that more reputable and experienced VC firms are able per se to overcome informational asymmetries rather than having to underprice their issues in order to allow for successful IPOs.

Insert Table 8 here

\section{$7 \quad$ Extensions and robustness}

In order to strengthen our arguments and provide for a better understanding of the underlying mechanisms we firstly extend our analysis and consider further potential determinants of the going-private decisions. Secondly, we provide a number of robustness checks for our results.

\subsection{Financial and operative performance}

Up to now we have based our analysis on the assumption that the going-private decision is driven by corporate governance considerations. A further hypothesis obviously is that the going-private decision is (also) determined by the firms' performance: Firms which are doing badly in terms of financial performance (i.e. with regard to stock price developments) as well as with regard to operational performance will eventually leave the exchange and become private. A look into the descriptive statistics suggests that operative and financial performance seem to play an important role in the going-public decision. Table 9 reveals significant differences in the change of various operational performance measures between the going-private subsample and the control group with the former displaying a significantly more negative trend. Obviously the deteriorating performance added to the increased likelihood to go private. The difference in performance changes is persistent across different time periods (3,5 and 10 years) as well as across different profitability measures (i.e. ebit/assets as well as net income/equity). Only for the 10 year's period 
the differences becomes statistically less significant which is not least due to the fact that the sample of firms which went private becomes significantly smaller after 10 years. This difference in profitability changes is also existing between the VC-backed and the nonVC-backed sample. This finding is rather little surprising given the large dominance of VC-backed firms in the going private sample.

Insert Table 9 here

Table 9 also reveals significant differences in financial performance between the goingprivate sample and the control group of firms. Firms in the going-private sample have performed substantially worse with regard to the development of share prices as compared to firms which remained on the exchange. While median share prices for firms eventually went private decreased in all time periods considered (3,5 and 10 years), the opposite is true for firms which stood on the exchange. The differences between the two type's financial performance is statistically as well as economically significant. The differences between the two samples are for the median firms close to 10 percent p.a. for the 3 yearperiod and after all for the 5 and 10 year-periods more than 7 and 3 percent respectively. Pretty much the same pattern can be observed when comparing VC with non-VC backed firms.

Against this background, the obvious question is whether our main story, namely that VCs are more likely and able to bring marginal firms to the exchange is robust if we control for financial as well as operating. In the strict sense, the answer is clearly to the affirmative. The results of the logit regression in which we only include variables at the time of the IPO and ask whether these variable (including the VC-backing dummy) do have predictive power for the firm's probability to go private is not influenced by the performance consideration, which occur later on. In a more general sense, we have to ask ourselves whether the inclusion of financial and operative performance does have an effect on the VC-backing dummy in the Cox regression.

\section{Insert Table 10 here}

Table 10 aims to answer this period. It turns out, that despite the fact that at least financial performance has a significant impact on the going-private probability (see models (1)-(3) in Table 10), our overall story remains unaltered. The VC-backed variable remains highly significant. The coefficient of the VC-backed variable is only slightly reduced. Hence, even after taking post-IPO operative and financial performance into account, the basic finding, that VC-backing increases very strongly the likelihood that firms goes public remains intact. What about the tests of our hypotheses. Once, again the Cox regression in table 10 try to give an answer on this (see models (4) and (5)). The results signal the robustness of our findings in this respect as well. All our findings on the underpricing 
hypothesis (model (4)) as well as on the certification/grandstanding hypothesis (model (5)) go through. The latter results become even slightly stronger. Hence, we can conclude that all our results are robust vis-a-vis the inclusion of measures for operational as well as financial performance.

\subsection{Impact of IPO year}

Our data sample embraces quite a long time period. During this time period we observe a number of features which vary over time, as indicated in our discussion of the aggregated data. Most notably, we observe a significant increase in the hoing-private transactions in the post 1990 period as compared to the situation prior to 1990. Against this background it seems appropriate to check whether the patterns we have carved out in our discussion so far hold true for the entire time period or are driven by subperiods in which market transactions (in either direction, i.e., going-private or going-public) has been especially active. For example, are the firms which went public in the dot-com bubble years significantly different as compared to the other firms, with a significantly different going-private pattern? There exist a number of potential approaches to address this potential problem. First, we could have split the sample into parts, e.g. in a subsample of firms which have had their IPO prior to 1998 and those which went public post 1998. The problem with this approach is that it distorts against the latter subsample in the sense that these firms are on average public for a much shorter average time period since our observation period ends 2011. An even more problematic way to deal with the issue would have been to split the sample according to the going-private years: to divide along the lines of the going-private years (e.g. considering in one sample only the going private years post 1998 and pre-1998). This would have introduced a high degree of endogeneity into our sample split.

We therefore chose what we think is the most appropriate way to address the issue: to allow for IPO-fixed effects which control for unobserved effects of the years in which the respective firms went public. We introduce these IPO year fixed effects into our Cox regression with which we test our hypothesis. Allowing for IPO year fixed effects leaves our results unchanged. All our previous results carry over to the inclusion of the IPO year controls (see Table 10).

Insert Table 11 here

\subsection{Different Going-Private Modes}

So far, we have compared two types of firms. Firms which left the exchange either because they were merged with or acquired by another firm or because they were delisted but still 
existing (the CRSP 200 and 500 codes, respectively) with the control group (all other firms). By allowing for different sample splits we ask whether our results are robust vis-avis the precise going-private mode of our going-private subsample but also by with regard to a different composition of the control group. As a first step. we address the latter step and eliminate all firms in the control group which eventually went bankrupt (and therefore left the exchange while not being involved in an active going-private decision). We find that the elimination of these firms (about 200 firms) leave our basic finding as well as the hypotheses test unchanged. We achieve similar finings if we drop in a second step the delisting cases from our going-private subsample (the 500 codes in CRSP, about 950 firms). This change in sample composition leads to (small) changes in the coefficients but not of the level of statistical and economic significance.

An obviously interesting question is whether firms which are bought by private equity investors in the course of the going-private process (typically referred to a leveraged buyout) follow the same mechanisms as the ones described above. That is, are firms which are initially backed by VCs (an active investor) are more likely to go private once again into the hands of another active investors which takes the firm private in order to e.g. improve its corporate governance? In this particular case we could interpret the beingpublic spell as a temporary exception to the firm's long-run need for an active investor who controls the firm tightly. Unfortunately we are not able to check this directly, since we are lacking data on the whether firms went private in the course of a leveraged buyout. But we are able to look into this issue indirectly by focusing on those firms only which went private and where shareholders received cash payments only. Obviously the class of firms is larger than the one of leveraged buyouts, but contains leveraged buyouts. Undertaken this sample split allows us to provide an affirmative answers to the above question. Even if we only compare these firms (which are in the 233 code of CRSP) with all firms in the control group our qualitative findings remain unchanged. This suggests that there are indeed firms which stay only temporarily on the exchange, starting as VC-backed firm (at the IPO) and going private (via a leverage buyout). Furthermore, being acquired in the course of a leverage buyout is more likely for initially VC-backed firms, a quite surprising and highly interesting result which calls for further research on the details of the mechanics behind this.

\section{Conclusion}

The main aim of this paper was to investigate the observed patterns associated with the going-public and going-private process: namely that firms backed by VC in the course of their IPO are much more likely to revert this step and turn private again. In a first step, we showed by using firm and market characteristics in Cox proportional hazard model that the impact of the VC-backed variable on the going-private probability survives a more thorough analysis. When investigating the determinants of the ability of VCs to 
bring marginal firms to the exchange we found a rather clear-cut picture and evidence for the ability of experienced and reputable VCs to signal the quality of the firm, i.e. certify this vis-a-vis potential shareholder, even without having to pay for this via underpricing. Thereby, we not only shed new light on the determinants of the going-private process. Even more importantly we allow for a quite different interpretation of $\mathrm{VC}$ exits via an IPO. Rather than being the silver bullet and the final step in the life-time of a firm, we show that it is more likely only a temporary step of the firm which is made possible by experienced and reputable VCs backing the company and allowing to overcome informational asymmetries vis-a-vis potential shareholders in public markets.

Obviously there are a number of routes this issue can be taken in future research. What role do private equity firms (as successors of VCs firms in overtaking concentrated ownership) play in the going-private decision of initially VC-backed firms. To what extent are the dynamics of the VCs divestment in and after the IPO govern the going-private decision in general and its speed in particular?

\section{References}

Aghion, P., P. Bolton, and J. Tirole (2004): "Exit options in Corporate Finance: Liquidity versus Incentives," Review of Finance, 8, 327-353.

Barry, C. B., C. J. Muscarella, J. W. P. III, and M. R. Vetsuypens (1990): "The role of venture capital in the creation of public companies: Evidence from the going-public process," Journal of Financial Economics, 27(2), 447 - 471.

Barry, C. B., C. J. Muscarella, J. W. I. Peavy, and M. R. Vetsuypens (1990): "The role of venture capital in the creation of public companies: Evidence from the going-public process," Journal of Financial Economics, 27(2), 447 - 471.

Bayar, O., and T. J. Chemmanur (2011): "IPOs versus Acquisitions and the Valuation Premium Puzzle: A Theory of Exit Choice by Entrepreneurs and Venture Capitalists," Journal of Financial and Quantitative Analysis, pp. 1-63.

Bharath, S., And A. Dittmar (2010): "Investor activism and takeovers," Review of Financial Studies, 23(5), 1771-1818.

Bienz, C., And U. Walz (2011): "Venture Capital Exit Rights," Journal of Economics and Management.

Black, B. S., And R. J. Gilson (1998): "Venture capital and the structure of capital markets: banks versus stock markets," Journal of Financial Economics, 47(3), 243 277 . 
Brav, A., And P. A. Gompers (1997): "Myth or Reality? The Long-Run Underperformance of Initial Public Offerings: Evidence from Venture and Nonventure CapitalBacked Companies," Journal of Finance, 52(5), 1791-1821.

Cumming, D. J. (2008): "Contracts and Exits in Venture Capital Finance," Review of Financial Studies, 21, 1947-1982.

Cumming, D. J., and S. Johan (2008): "Preplanned Exit Strategies in Venture Capital," European Economic Review, 52, 1209-1241.

Giot, P., And A. Schwienbacher (2007): "IPOs, trade sales and liquidations: Modelling venture capital exits using survival analysis," Journal of Banking and Finance, $31(3), 679-702$.

Gompers, P., And J. Lerner (2004): The Venture Capital Cycle, 2nd Ed. MIT Press, Cambridge (Mass.) and London.

Gompers, P. A. (1996): "Grandstanding in the Venture Capital Industry," Journal of Financial Economics, 42, 133 - 156.

Grinblatt, M., and C. Y. Hwang (1989): "Signalling and the Pricing of New Issues," The Journal of Finance, 44(2), pp. 393-420.

H., J., And Cochrane (2005): "The risk and return of venture capital," Journal of Financial Economics, 75(1), 3 - 52.

Hirsch, J., ANd U. WAlz (2012): "Why Do Contracts Differ between Venture Capital Types?," Small Business Economics.

Jeng, L. A., And P. C. Wells (2000): "The determinants of venture capital funding: evidence across countries," Journal of Corporate Finance, 6(3), 241 - 289.

Kyriakos, F., And M. Ueda (2007): "Knowing Who You Are Matters: A Theory of Young Firms and Mature Firms," Working Paper.

Lee, P., and S. Wahal (2004a): "Grandstanding, certification, and the underpricing of venture capital backed IPOs," Journal of Financial Economics, 73, 375 - 407.

LeE, P. M., And S. Wahal (2004b): "Grandstanding, certification and the underpricing of venture capital backed IPOs," Journal of Financial Economics, 73(2), 375 - 407.

LERNER, J. (1994): "Venture capitalists and the decision to go public," Journal of Financial Economics, 35, 293-316.

Li, X., And R. Masulis (2006): "Venture capital investments by IPO underwriters: certification, alignment of interest, or moral hazard?," Unpublished Working Paper. 
Lin, T., And R. L. Smith (1998): "Insider reputation and selling decisions: the unwinding of venture capital investments during equity IPOs," Journal of Corporate Finance, 4, 241263.

Megginson, W. L., And K. A. Weiss (1991): "Venture Capitalist Certification in Initial Public Offerings," The Journal of Finance, 46(3), pp. 879-903.

Mehran, H., and S. Perstiani (2010): "Financial Visibility and the Decision to Go Private," Review of Financial Studies, 23(2), 519-547.

NAHATA, R. (2008): "Venture capital reputation and investment performance," Journal of Financial Economics, 90(2), 127 - 151.

Neus, W., AND U. WAlz (2005): "Exit timing of venture capitalists in the course of an initial public offering," Journal of Financial Intermediation, 14(2), 253 - 277.

RitTeR, J. (1984): "The "Hot Issue" Market of 1980," Journal of Business.

Ritter, J. R., And I. Welch (2002): "A Review of IPO Activity, Pricing, and Allocations," Journal of Finance, 57(4), 1795-1828.

T., C., S. He, and D. Nandy (2010): "The Going Public Decision and the Product Market: Empirical Evidence," Review of Financial Studies, 23(5), 1855-1908.

Zingales, L. (1995): "Insider Ownership and the Decision to Go Public," Review of Economic Studies, 62(3), 425-448. 


\section{Figures and Tables}

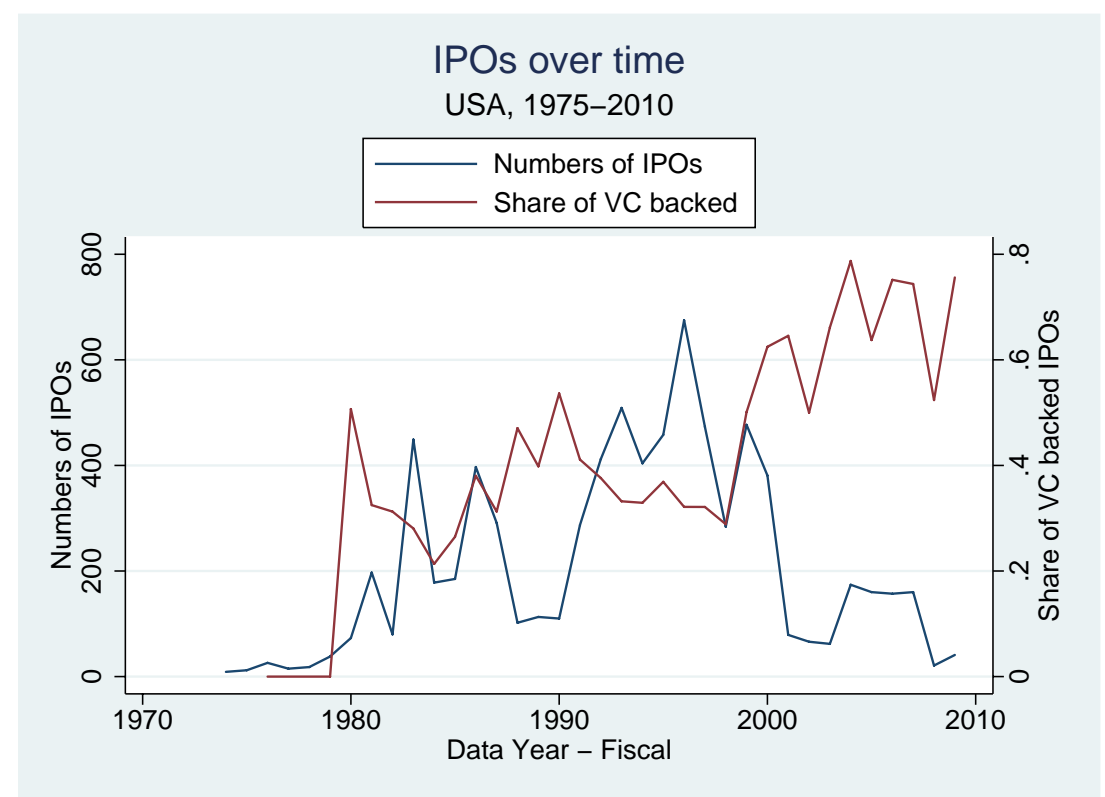

Figure 1: Absolute (and relative) Number of IPOs

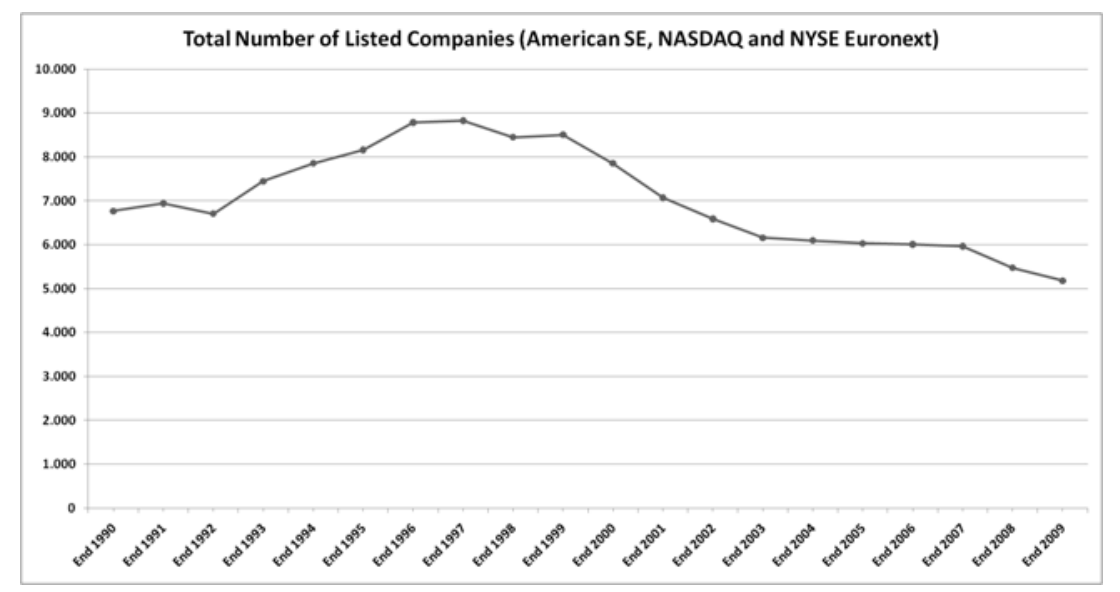

Figure 2: Number of listed companies 


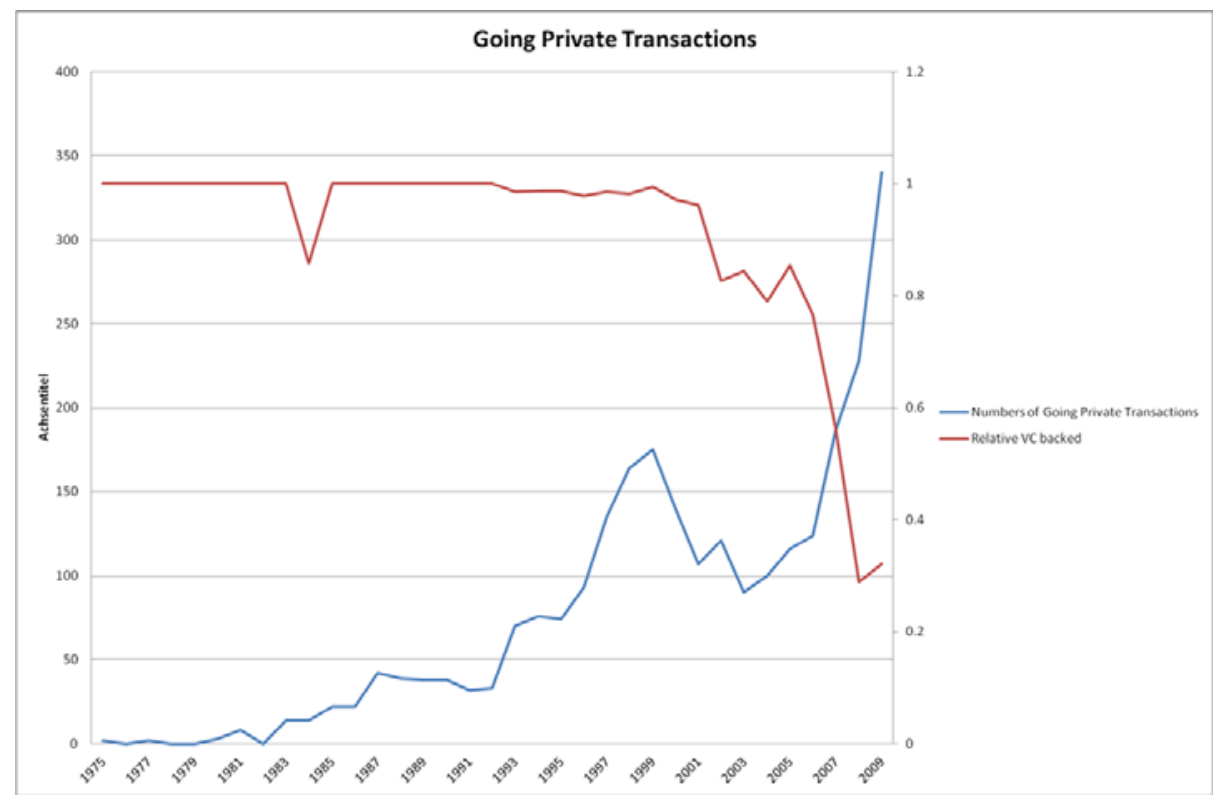

Figure 3: Absolute (and relative) Number of Going Private Cases 


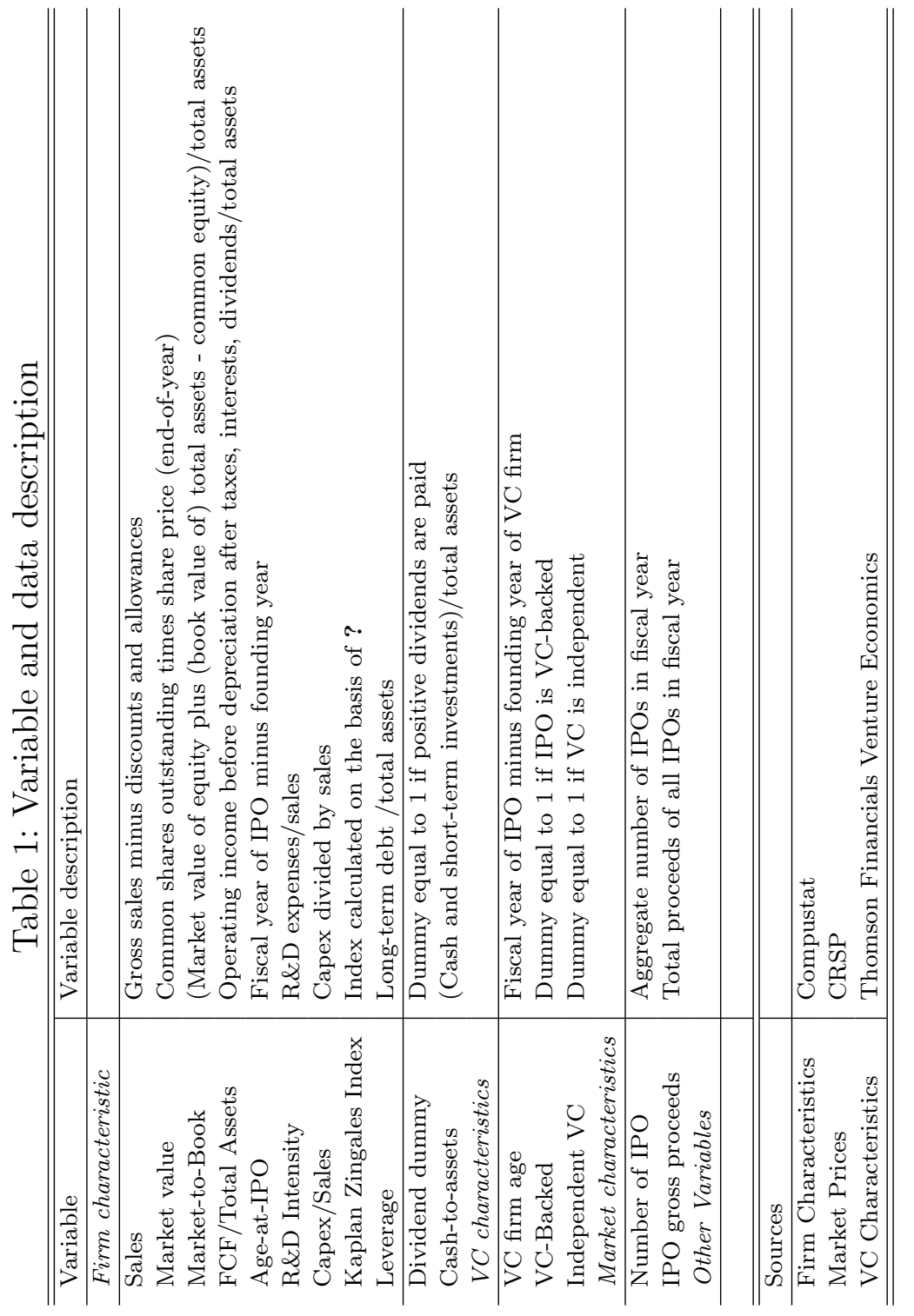


Table 2: Comparison - going private subsample ; date of IPO

In this table we display the main firm characteristics for our two subsamples: the going private subsample as well as the control group at the time of the IPO of the respective firm. We present means as well as medians and report potential significance levels of the comparison between the two groups.,,$++++++(* * *, * *, *)$ represent significance levels for differences in means (medians) at the 1, 5, 10 percent level, respectively.

\begin{tabular}{lcccccccc}
\hline \hline \multirow{2}{*}{ Variable } & \multicolumn{3}{c}{ Going private subsample } & \multicolumn{3}{c}{ Still public } \\
& Obs & Mean & Median & Sig. & Sig & Obs & Mean & Median \\
\hline \hline Age at IPO & 1924 & 11.69 & 7 & +++ & $* * *$ & 1892 & 18.89 & 9 \\
FCF/Total assets & 2187 & -0.077 & 0.029 & & $* * *$ & 3286 & -0.057 & 0.052 \\
Market value & 2358 & 400.6 & 104.1 & +++ & $* * *$ & 3553 & 873.4 & 148.2 \\
Sales & 2503 & 166.1 & 29.88 & +++ & $* * *$ & 3907 & 637.6 & 60.36 \\
Total assets & 2512 & 314.9 & 50.01 & +++ & $* * *$ & 3940 & 1382 & 111.5 \\
Market-to-Book value & 2346 & 3.909 & 2.408 & & $* * *$ & 3484 & 6.556 & 1.722 \\
Kaplan-Zingales index & 1780 & 0.403 & 0.617 & & $* * *$ & 2331 & 1.356 & 0.549 \\
R\&D intensity & 1643 & 3.082 & 0.139 & & $* * *$ & 1925 & 3.048 & 0.045 \\
Leverage & 2505 & 0.113 & 0.018 & +++ & $* * *$ & 3924 & 0.151 & 0.050 \\
Capex/sales & 2375 & 1.190 & 0.065 & & $* * *$ & 3475 & 1.737 & 0.051 \\
Cash/Total assets & 2509 & 0.395 & 0.371 & +++ & $* * *$ & 3930 & 0.263 & 0.124 \\
Dividend Dummy & 2559 & 0.307 & 0 & +++ & $* * *$ & 4180 & 0.424 & 0
\end{tabular}

Table 3: Comparison - going private subsample ; 5 year after IPO

In this table we display the development of main firm characteristics for our two subsamples for the 5 years following the IPO: the going private subsample as well as the control group. We present means as well as medians and report potential significance levels of the comparison between the two groups.,,$++++++(* * *, * *, *)$ represent significance levels for differences in means (medians) at the 1, 5, 10 percent level, respectively.

\begin{tabular}{lcccccccc}
\hline \hline & \multicolumn{3}{c}{ Going private subsample } & & \multicolumn{3}{c}{ Still public } \\
Variable & Obs & Mean & Median & Sig. & Sig. & Obs & Mean & Median \\
\hline \hline Sales growth (in \%) & 1198 & 1.679 & 0.941 & +++ & $*$ & 2894 & 1.613 & 1.016 \\
Asset growth (in \%) & 1309 & 1.384 & 0.606 & ++ & $* * *$ & 3071 & 1.536 & 0.924 \\
Leverage growth & 919 & 0.360 & -0.337 & & $* * *$ & 2296 & 0.360 & -0.127 \\
Change in market value & 1182 & 0.621 & -0.083 & +++ & $* * *$ & 2685 & 1.271 & 0.535 \\
Change in Capex/sales & 1231 & 0.066 & -0.389 & +++ & $* * *$ & 2623 & 0.207 & -0.174 \\
Change in market-to-book & 1226 & -0.059 & -0.292 & +++ & $* * *$ & 2988 & 0.050 & -0.067 \\
Change in FCF/Total assets & 1085 & -17.26 & -0.186 & & $* * *$ & 2518 & -2.486 & -0.008 \\
Change in Cash/Total assets & 1326 & -0.013 & -0.345 & +++ & $* * *$ & 3093 & 0.132 & -0.265
\end{tabular}


Table 4: Comparison - VC-backed versus non-VC-backed firms; date of IPO

In this table we display the main firm characteristics for our two subsamples: the VC-backed and the non VC-backed companies. We present means as well as medians and report potential significance levels of the comparison between the two groups.,,$++++++(* * *, * *, *)$ represent significance levels for differences in means (medians) at the $1,5,10$ percent level, respectively.

\begin{tabular}{lcccccccc}
\hline \hline \multirow{2}{*}{ Variable } & \multicolumn{4}{c}{ VC-backed } & \multicolumn{4}{c}{ Non VC-backed } \\
& Obs & Mean & Median & Sig. & Sig & Obs & Mean & Median \\
\hline \hline Age at IPO & 2567 & 12.75 & 7 & +++ & $* * *$ & 1246 & 20.67 & 11 \\
FCF/Total assets & 2678 & -0.063 & 0.039 & & $* * *$ & 2786 & -0.069 & 0.048 \\
Market value & 2827 & 599.8 & 161.1 & ++ & $* * *$ & 2940 & 791.9 & 93.92 \\
Sales & 3027 & 208.6 & 38.08 & +++ & $* * *$ & 3370 & 677.8 & 49.01 \\
Total assets & 3030 & 313.3 & 66.69 & +++ & $* * *$ & 3405 & 1555 & 94.33 \\
Market-to-Book value & 2823 & 4.128 & 2.558 & & $* * *$ & 2864 & 6.961 & 1.455 \\
Kaplan-Zingales index & 2324 & 0.372 & 0.639 & & $* * *$ & 1759 & 1.707 & 0.483 \\
R\&D intensity & 2101 & 3.693 & 0.146 & & $* * *$ & 1464 & 2.129 & 0.024 \\
Leverage & 3019 & 0.123 & 0.018 & +++ & $* * *$ & 3392 & 0.153 & 0.062 \\
Capex/sales & 2907 & 0.934 & 0.066 & & $* * *$ & 2933 & 1.885 & 0.047 \\
Cash/Total assets & 3026 & 0.419 & 0.406 & +++ & $* * *$ & 3395 & 0.215 & 0.095 \\
Dividend Dummy & 3052 & 0.316 & 0 & +++ & $* * *$ & 3673 & 0.434 & 0
\end{tabular}

Table 5: Probability to go private

In this table we present our multivariate estimations. The first two models are display Cox regression with the left hand side representing the time since IPO. The third model displays a probit regression with the going private dummy which is one if the firm has left the exchange at a certain point in time while being zero if the firm is still public.

\begin{tabular}{|c|c|c|c|c|c|c|}
\hline & \multicolumn{2}{|c|}{ Cox regression } & \multicolumn{2}{|c|}{ Cox regression } & \multicolumn{2}{|c|}{ Probit } \\
\hline & Coefficients & $\mathrm{z}$ & Coefficient & $\mathrm{z}$ & Coeff. & $\mathrm{z}$ \\
\hline Log Sales & -0.187 & -10.00 & -0.193 & -7.95 & -0.076 & -3.33 \\
\hline Capex/Sales & -0.030 & -1.63 & -0.037 & -0.96 & 0.001 & 0.49 \\
\hline Dividend Dummy & -0.204 & -2.57 & -0.116 & -1.13 & -0.056 & -0.93 \\
\hline Market-to-Book & -0.075 & -4.89 & -0.074 & -4.44 & -0.005 & -0.85 \\
\hline Total Assets & 0.000 & 2.75 & -0.000 & -0.83 & 0.000 & 1.65 \\
\hline Market value & -0.000 & -2.34 & -0.000 & -1.08 & -0.000 & -1.83 \\
\hline FCF/Total Assets & -0.128 & -6.37 & -0.115 & -5.01 & -0.486 & -3.69 \\
\hline Leverage & 0.102 & 1.27 & 0.110 & 1.29 & 0.058 & 0.36 \\
\hline Cash/Assets & -0.779 & -5.77 & -0.708 & -4.54 & -0.346 & -2.60 \\
\hline VC-backed & 1.813 & 22.30 & 1.748 & 16.69 & 1.372 & 22.24 \\
\hline Age-at-IPO & -0.003 & -1.71 & -0.003 & -1.10 & -0.002 & -1.47 \\
\hline Kaplan-Zingales Dummy & -0.069 & -0.98 & 0.010 & 0.12 & -0.138 & -1.91 \\
\hline R\&D Intensity & & & -0.006 & -1.48 & & \\
\hline Industry + year dummies & \multicolumn{2}{|l|}{ yes } & \multicolumn{2}{|l|}{ yes } & \multicolumn{2}{|c|}{ yes } \\
\hline No of observ & \multicolumn{2}{|c|}{28397} & \multicolumn{2}{|l|}{18494} & \multicolumn{2}{|c|}{3129} \\
\hline
\end{tabular}


Table 6: Testing the hot-issue market hypothesis

In this table we test our hot-issue market hypothesis. All models display Cox regressions with the left hand side representing the time since IPO. We use three proxies for hot-issue markets. First, we resort to the number of IPOs which have taken place in the same fiscal year as the particular firm went public (No IPOs at time of IPO). Second, we use the IPO proceeds in the year of the IPO of the particular firm (IPO proceeds). Third, we use the total annual returns in the NASDAQ as proxy for a hot issue market.

\begin{tabular}{lcccccc}
\hline \hline & \multicolumn{2}{c}{ Cox regression } & \multicolumn{2}{c}{ Cox regression } & \multicolumn{2}{c}{ Cox regression } \\
\hline & Coefficients & $\mathrm{z}$ & Coefficient & $\mathrm{z}$ & Coefficient & $\mathrm{z}$ \\
\hline \hline Log Sales & -0.185 & -9.85 & -0.184 & -9.78 & -0.185 & -9.85 \\
No IPOs at time of IPO & 0.001 & 1.48 & & & & \\
No IPOs * VC dummy & -0.000 & -0.27 & & & & \\
IPO proceeds & & & 0.000 & 6.48 & & 5.97 \\
IPO proceeds * VC dummy & & & -0.000 & -5.67 & & -6.30 \\
Nasdaq & & & & & 0.000 & -1.61 \\
Nasdaq * VC dummy & & & & & -0.000 & -2.54 \\
Capex/Sales & -0.031 & -1.62 & -0.030 & -1.61 & -0.030 & -2.50 \\
Dividend Dummy & -0.193 & -2.42 & -0.186 & -2.34 & -0.202 & 2.80 \\
Market value & -0.000 & -2.33 & -0.000 & -2.49 & -0.000 & -4.85 \\
Total Assets & 0.000 & 2.66 & 0.000 & 2.76 & 0.000 & -6.40 \\
Market-to-book & -0.073 & -4.77 & -0.073 & -4.79 & -0.074 & 1.28 \\
FCF/Total Asset & -0.125 & -6.25 & -0.128 & -6.36 & -0.128 & -5.71 \\
Leverage & 0.101 & 1.27 & 0.099 & 1.24 & 0.102 & 18.56 \\
Cash/Assets & -0.789 & -5.85 & -0.801 & -5.91 & -0.773 & -1.70 \\
VC-backed & 1.878 & 9.14 & 2.54 & 15.74 & 2.34 & -0.95 \\
Age-at-IPO & -0.003 & -1.61 & -0.003 & -1.58 & -0.003 \\
Kaplan-Zingales Dummy & -0.069 & -1.00 & -0.065 & -0.93 & -0.067 & yes \\
Industry + year dummies & yes & & & yes & & 28397 \\
No of observ & 28397 & & & &
\end{tabular}


Table 7: Testing the grandstanding and the certification hypotheses

In this table we test the grandstanding as well as the certification hypothesis. All models display Cox regressions with the left hand side representing a dummy which is one if the particular firm has left the exchange in the year under observation and zero otherwise. Besides the variables used in our standard Cox regression we employ four proxies with which we test the gradstanding as well as the certification hypotheses. These variables are: the number of IPOs the VC who backs the particular company has undertaken (Number-IPO-VC), the age of the VC firm at the time of the IPO (Age-VC), the cumulative market share of the VC in total market capitalizations of IPOs up to the year of the IPO (Market-sharemcap- $\mathrm{VC}$ ) as well as a dummy taking a value of one if the $\mathrm{VC}$ is an independent $\mathrm{VC}$ or zero if the $\mathrm{VC}$ is a captive $\mathrm{VC}$ (Dummy-independent).

\begin{tabular}{|c|c|c|c|c|c|c|c|c|c|c|}
\hline & \multicolumn{2}{|c|}{ Model (1) } & \multicolumn{2}{|c|}{ Model (2) } & \multicolumn{2}{|c|}{ Model (3) } & \multicolumn{2}{|c|}{ Model (4) } & \multicolumn{2}{|c|}{ Model (5) } \\
\hline & Coefficients & $\mathrm{z}$ & Coefficient & $\mathrm{z}$ & Coeff. & $\mathrm{z}$ & Coeff. & $\mathrm{z}$ & Coeff. & $\mathrm{z}$ \\
\hline Log Sales & -0.187 & -9.96 & -0.187 & "-10.00 & -0.187 & "-10.01 & -0.190 & "-10.09 & -0.190 & -10.10 \\
\hline Capex/Sales & -0.030 & -1.62 & -0.030 & -1.63 & -0.030 & -1.62 & -0.031 & -1.65 & -0.031 & -1.64 \\
\hline Dividend Dummy & -0.204 & -2.56 & -0.204 & -2.57 & -0.202 & -2.56 & -0.200 & -2.50 & -0.197 & -2.47 \\
\hline Market value & -0.000 & -2.34 & -0.000 & -2.34 & -0.000 & -2.33 & -0.000 & -2.30 & -0.000 & -2.30 \\
\hline Total Assets & 0.000 & 2.75 & 0.000 & 2.75 & 0.000 & 2.75 & 0.000 & 2.73 & 0.000 & 2.73 \\
\hline Market-to-book & -0.074 & -4.89 & -0.075 & -4.89 & -0.075 & -4.86 & -0.074 & -4.78 & -0.073 & -4.76 \\
\hline FCF/Total Asset & -0.128 & -6.37 & -0.127 & -6.37 & -0.128 & -6.33 & -0.125 & -6.26 & -0.125 & -6.22 \\
\hline Leverage & 0.102 & 1.27 & 0.102 & 1.27 & 0.104 & 1.30 & 0.104 & 1.28 & 0.105 & 1.31 \\
\hline Cash/Assets & -0.783 & -5.79 & -0.780 & -5.78 & -0.784 & -5.81 & -0.819 & -6.03 & -0.822 & -6.04 \\
\hline VC-backed & 1.81 & 22.14 & 1.81 & 22.14 & 1.81 & 22.23 & 1.71 & 19.21 & 1.71 & 19.10 \\
\hline Age-at-IPO & -0.003 & -1.71 & -0.003 & -1.72 & -0.003 & -1.69 & -0.003 & -1.68 & -0.003 & -1.66 \\
\hline Kaplan-Zingales Dummy & -0.069 & -0.98 & -0.06 & -0.98 & -0.071 & -1.01 & -0.071 & -1.01 & -0.072 & -1.03 \\
\hline Number-IPO-VC & 0.0003 & 0.45 & & & & & & & -0.0001 & -0.13 \\
\hline Age-VC & & & 0.0003 & 0.28 & & & & & -0.0001 & -0.06 \\
\hline Market-share-mcap-VC & & & & & 1.322 & 2.14 & & & 1.34 & 2.13 \\
\hline Dummy-Independent & & & & & & & 0.175 & 2.89 & 0.177 & 2.85 \\
\hline Industry + year dummies & \multicolumn{2}{|l|}{ yes } & \multicolumn{2}{|c|}{ yes } & \multicolumn{2}{|c|}{ yes } & \multicolumn{2}{|c|}{ yes } & \multicolumn{2}{|c|}{ yes } \\
\hline No of observ & \multicolumn{2}{|l|}{28397} & \multicolumn{2}{|c|}{28397} & \multicolumn{2}{|c|}{28397} & \multicolumn{2}{|c|}{28397} & \multicolumn{2}{|c|}{28397} \\
\hline
\end{tabular}

Table 8: Underpricing

In this table we explore determinants of underpricing. We regress the level of underpricing (market price at the end of the first day of trading relative to the issue price) on firm as well as $\mathrm{VC}$ characteristics

\begin{tabular}{|c|c|c|c|c|c|c|}
\hline & Coefficients & $\mathrm{t}$ & Coefficient & $\mathrm{t}$ & Coefficient & $\mathrm{t}$ \\
\hline Log Sales & 0.041 & 1.04 & 0.041 & 1.04 & 0.041 & 1.04 \\
\hline Total Assets & -0.000 & -0.39 & -0.000 & -0.39 & -0.000 & -0.39 \\
\hline Market-to-book & 0.022 & 2.72 & 0.022 & 2.72 & 0.022 & 2.72 \\
\hline FCF/Total Asset & -0.0098 & -0.04 & -0.0099 & -0.04 & -0.0100 & -0.04 \\
\hline Leverage & -0.201 & -0.63 & -0.201 & -0.63 & -0.201 & -0.62 \\
\hline Cash/Assets & 0.494 & 1.91 & 0.494 & 1.91 & 0.497 & 1.90 \\
\hline Age-at-IPO & -0.0016 & -0.53 & -0.0016 & -0.53 & -0.0016 & -0.53 \\
\hline Capex/Sales & -0.010 & -0.18 & -0.010 & -0.18 & -0.010 & -0.18 \\
\hline Num-IPOs-at-IPO & 0.0006 & 1.91 & 0.0006 & 1.91 & 0.0006 & 1.91 \\
\hline Dummy-Independent & -0.090 & -0.69 & -0.093 & -0.79 & -0.090 & -0.69 \\
\hline Age-at-IPO-VC & -0.0002 & -0.05 & & & -0.0002 & -0.05 \\
\hline Market-share-mcap-VC & & & 0.052 & 0.02 & 0.054 & 0.02 \\
\hline No of observ & 3141 & & 3141 & & 3141 & \\
\hline Adj. $R^{2}$ & 0.0039 & & 0.0039 & & 0.0036 & \\
\hline
\end{tabular}




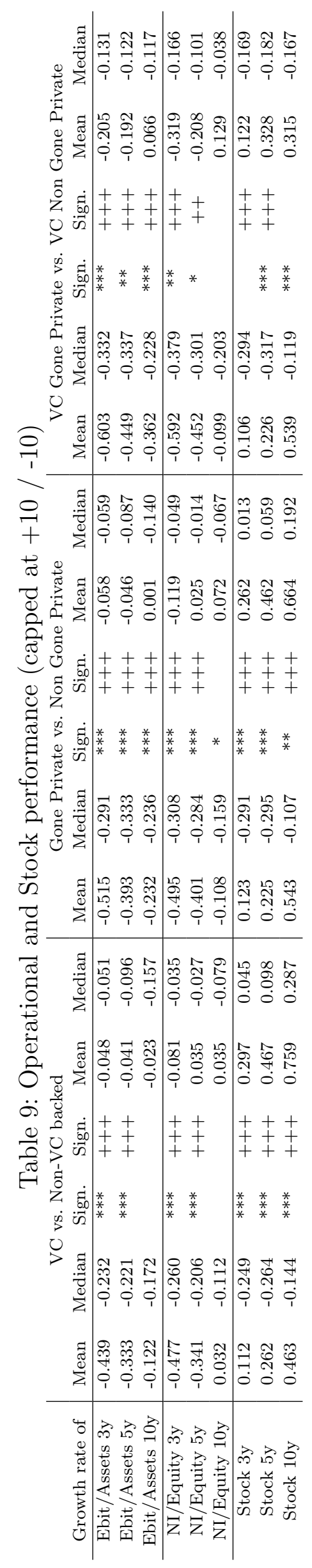


Table 10: Impact of financial and operative performance

In this table we check the robustness of our findings by controlling for the financial and operative performance of the firms. All models display Cox regressions with the left hand side representing a dummy which is one if the particular firm has left the exchange in the year under observation and zero otherwise. We use three main variables to control for financial and operative performance: the 5-year growth rate of net income /equity and of ebit/assets for operative and the five-year growth rate of the share price for financial performance.

\begin{tabular}{|c|c|c|c|c|c|c|c|c|c|c|}
\hline & \multicolumn{2}{|c|}{ Model (1) } & \multicolumn{2}{|c|}{ Model (2) } & \multicolumn{2}{|c|}{ Model (3) } & \multicolumn{2}{|c|}{ Model (4) } & \multicolumn{2}{|c|}{ Model (5) } \\
\hline & Coeff. & $\mathrm{z}$ & Coeff. & $\mathrm{z}$ & Coeff. & $\mathrm{z}$ & Coeff. & $\mathrm{z}$ & Coeff. & $\mathrm{z}$ \\
\hline Log Sales & 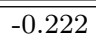 & -9.56 & -0.220 & -9.49 & -0.204 & $\begin{array}{c}-9.43 \\
\end{array}$ & -0.202 & -8.09 & 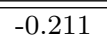 & -8.39 \\
\hline Capex/Sales & -0.049 & -1.31 & -0.049 & -1.30 & -0.019 & -1.27 & -0.036 & -1.06 & -0.040 & -1.16 \\
\hline Dividend Dummy & -0.311 & -2.97 & -0.316 & -3.01 & -0.230 & -2.43 & -0.276 & -2.53 & -0.279 & -2.55 \\
\hline Market value & -0.000 & -1.80 & -0.000 & -1.80 & -0.000 & -2.00 & -0.000 & -1.96 & -0.000 & -1.74 \\
\hline Total Assets & 0.000 & 2.61 & 0.000 & 2.61 & 0.000 & 2.53 & 0.000 & 2.68 & 0.000 & 2.54 \\
\hline Market-to-book & -0.049 & -2.59 & -0.049 & -2.57 & -0.077 & -3.82 & -0.055 & -2.38 & -0.055 & -2.38 \\
\hline FCF/Total Asset & -0.07 & -2.67 & -0.07 & -2.66 & -0.098 & -4.43 & -0.072 & -2.50 & -0.068 & -2.33 \\
\hline Leverage & 0.052 & 0.60 & 0.052 & 0.60 & 0.260 & 2.57 & 0.262 & 2.41 & 0.239 & 2.17 \\
\hline Cash/Assets & -0.864 & -4.64 & -0.865 & -4.64 & -0.820 & -5.03 & -0.783 & -3.98 & -0.811 & -4.09 \\
\hline VC-backed & 1.50 & 16.15 & 1.50 & 16.14 & 1.84 & 19.74 & 2.37 & 12.92 & 1.49 & 13.05 \\
\hline Age-at-IPO & -0.003 & -1.06 & -0.0025 & -1.09 & -0.001 & -0.59 & -0.003 & -1.24 & -0.006 & -1.67 \\
\hline Kaplan-Zingales Dummy & -0.060 & -0.64 & -0.059 & -0.63 & -0.051 & -0.60 & -0.102 & -0.99 & -0.086 & -0.84 \\
\hline IPO gross proceeds & & & & & & & 0.0000 & 5.11 & & \\
\hline IPO grpr* VC dummy & & & & & & & -0.0000 & -5.79 & & \\
\hline Age-VC & & & & & & & & & -0.006 & -1.67 \\
\hline Market-share-mcap-VC & & & & & & & & & 0.206 & 2.16 \\
\hline Dummy-Independent & & & & & & & & & 5.389 & 2.33 \\
\hline $5 y$ gr Ebit/total assets & 0.002 & 0.48 & & & & & 0.004 & 0.95 & 0.0028 & 0.70 \\
\hline $5 y$ gr NI/Equity & & & -0.0001 & & & & 0.0003 & 0.67 & 0.0001 & 0.37 \\
\hline $5 y$ gr share price & & & & 0.022 & 2.24 & -0.036 & -1.38 & -0.037 & -1.48 \\
\hline Industry + year fixed effects & & & & & \multicolumn{2}{|c|}{ yes } & \multicolumn{2}{|c|}{ yes } & \multicolumn{2}{|c|}{ yes } \\
\hline No of observ & \multicolumn{2}{|c|}{25503} & \multicolumn{2}{|c|}{25520} & \multicolumn{2}{|c|}{24890} & \multicolumn{2}{|c|}{23949} & \multicolumn{2}{|c|}{23949} \\
\hline
\end{tabular}

Table 11: Impact of IPO time periods/years

In this table we check the robustness of our findings by controlling for the years in which the respective firms went public. We test the hot-issue market, the grandstanding as well as the certification hypothesis by allowing for IPO-year fixed effects. All models display Cox regressions with the left hand side representing a dummy which is one if the particular firm has left the exchange in the year under observation and zero otherwise. We use our main proxy for the hot-issue market hypothesis: IPO gross proceeds in general as well as the IPO gross proceeds times VC dummy interaction term. Wit regard to the grandstanding and the certification hypotheses we employ the age of the VC firm, the independent-VC dummy as well as the VC-market share in accumulated IPOs as proxies.

\begin{tabular}{|c|c|c|c|c|}
\hline & \multicolumn{2}{|c|}{ Hot-issue market hypothesis } & \multicolumn{2}{|c|}{ Grandstanding/certification hypothesis } \\
\hline & Coefficients & $\mathrm{z}$ & Coefficient & $\mathrm{z}$ \\
\hline Log Sales & -0.182 & -9.58 & -0.186 & -9.73 \\
\hline Capex/Sales & -0.030 & -1.60 & -0.031 & -1.63 \\
\hline Dividend Dummy & -0.194 & -2.44 & -0.198 & -2.47 \\
\hline Market value & -0.000 & -2.42 & -0.000 & -2.23 \\
\hline Total Assets & 0.000 & 2.82 & 0.000 & 2.71 \\
\hline Market-to-book & -0.069 & -4.53 & -0.068 & -4.42 \\
\hline FCF/Total Asset & -0.127 & -6.34 & -0.123 & -6.18 \\
\hline Leverage & 0.118 & 1.53 & 0.117 & 1.51 \\
\hline Cash/Assets & -0.810 & -5.94 & -0.859 & -6.24 \\
\hline VC-backed & 2.51 & 15.17 & 1.72 & 19.16 \\
\hline Age-at-IPO & -0.002 & -1.36 & -0.002 & -1.25 \\
\hline Kaplan-Zingales Dummy & -0.069 & -1.00 & -0.075 & -1.09 \\
\hline IPO gross proceeds & 0.0006 & 94.15 & & \\
\hline IPO gross proceeds* VC dummy & -0.000 & -5.18 & & \\
\hline Age-VC & & & -0.0003 & -0.26 \\
\hline Market-share-mcap-VC & & & 1.15 & 1.77 \\
\hline Dummy-Independent & & & 0.18 & 2.91 \\
\hline Industry + IPO year fixed effects & \multicolumn{2}{|c|}{ yes } & \multicolumn{2}{|c|}{ yes } \\
\hline No of observ & \multicolumn{2}{|c|}{28277} & \multicolumn{2}{|c|}{28277} \\
\hline
\end{tabular}




\section{CFS Working Paper Series:}

\begin{tabular}{|c|c|c|}
\hline No. & Author(s) & Title \\
\hline 2012/01 & Laura Moretti & $\begin{array}{l}\text { Inflation Targeting and Product Market } \\
\text { Deregulation }\end{array}$ \\
\hline 2011/31 & $\begin{array}{l}\text { Neil A. Doherty } \\
\text { Christian Laux } \\
\text { Alexander Muermann }\end{array}$ & Insuring Non-Verifiable Losses \\
\hline $2011 / 30$ & $\begin{array}{l}\text { Konstantinos Voutsinas } \\
\text { Richard Werner }\end{array}$ & $\begin{array}{l}\text { New Evidence on the Effectiveness of } \\
\text { 'Quantitative Easing' in Japan }\end{array}$ \\
\hline $2011 / 29$ & $\begin{array}{l}\text { Victor Lyonnet } \\
\text { Richard Werner }\end{array}$ & $\begin{array}{l}\text { The Lessons from QE and Other } \\
\text { 'Unconventional' Monetary Policies - } \\
\text { Evidence from the Bank of England }\end{array}$ \\
\hline $2011 / 28$ & $\begin{array}{l}\text { Dimitris Christelis } \\
\text { Loretti I. Dobrescu } \\
\text { Alberto Motta }\end{array}$ & $\begin{array}{l}\text { Early Life Conditions and Financial Risk- } \\
\text { Taking in Older Age }\end{array}$ \\
\hline $2011 / 27$ & $\begin{array}{l}\text { Dimitris Christelis } \\
\text { Dimitris Georgarakos } \\
\text { Tullio Jappelli }\end{array}$ & $\begin{array}{l}\text { Wealth Shocks, Unemployment Shocks and } \\
\text { Consumption in the Wake of the Great } \\
\text { Recession }\end{array}$ \\
\hline $2011 / 26$ & Richard A. Werner & $\begin{array}{l}\text { The Unintended Consequences of the Debt - - } \\
\text { - Will Increased Government Expenditure Hurt } \\
\text { the Economy? }\end{array}$ \\
\hline $2011 / 25$ & $\begin{array}{l}\text { Nikolaus Hautsch } \\
\text { Peter Malec } \\
\text { Melanie Schienle }\end{array}$ & $\begin{array}{l}\text { Capturing the Zero: A New Class of Zero- } \\
\text { Augmented Ditributions and Multiplicative } \\
\text { Error Processes }\end{array}$ \\
\hline $2011 / 24$ & $\begin{array}{l}\text { Nikolaus Hautsch } \\
\text { Lada M. Kyj } \\
\text { Peter Malec }\end{array}$ & $\begin{array}{l}\text { The Merit of High-Frequency Data in Portfolio } \\
\text { Allocation }\end{array}$ \\
\hline $2011 / 23$ & $\begin{array}{l}\text { Jingjing Chai } \\
\text { Raimond Maurer } \\
\text { Olivia S. Mitchell } \\
\text { Ralph Rogalla }\end{array}$ & $\begin{array}{l}\text { Lifecycle Impacts of the Financial and } \\
\text { Economic Crisis on Household Optimal } \\
\text { Consumption, Portfolio Choice, and Labor } \\
\text { Supply }\end{array}$ \\
\hline
\end{tabular}

Copies of working papers can be downloaded at http://www.ifk-cfs.de 